\title{
Kir6.2-Associated Diabetes Mellitus
}

National Cancer Institute

\section{Source}

National Cancer Institute. Kir6.2-Associated Diabetes Mellitus. NCI Thesaurus. Code C129760.

Diabetes mellitus caused by activating mutation(s) in the KCNJ11 gene, encoding the inwardly rectifying Kir6.2 subunit of the pancreatic beta cell adenosine triphosphatesensitive potassium channel. Note: Inactivating mutation(s) in the KCNJ11 gene result in hyperinsulinism. 